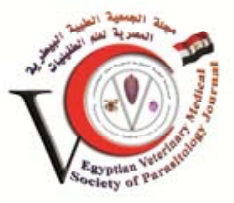

Original Article

\title{
Detection of Fasciola hepatica infection in cattle and Lymnaea truncatula snails in Dakhla Oasis, Egypt
}

Waleed M Arafa ${ }^{1}$, Ahmed I Hassan ${ }^{2}$, Samira AM Snousi ${ }^{2}$, Khaled M El-Dakhly ${ }^{1}$, Shawky M Aboelhadid ${ }^{1}$

${ }^{1}$ Department of Parasitology, Faculty of Veterinary Medicine Beni-Suef University, Egypt ${ }^{2}$ Regional Animal Health Research Laboratory, Animal Health Research Institute, ELDakhla, El-Wadi El-Gadid, Egypt

\begin{abstract}
:
Fasciolosis in Dakhla Oasis, Elwadi El-Gadid, Egypt was investigated in its final host, cattle, and the intermediate host, Lymnaea trancatula snail. The study was conducted in 7 localities of Dakhla Oasis, Egypt. Fecal samples from 300 cattle were collected and examined, liver of slaughtered animals were inspected for flukes in abattoir. Moreover, Lymnaeidae snails were harvested from water streams and examined also. Flukes mitochondrial DNA-targeting PCR assay was carried out to amplify the extracted genomic DNA from both of infected snails and adult worms. F. hepatica eggs were found in $31.33 \%$ of examined cattle. Moreover, abattoir liver inspection revealed that $11.56 \%$ harbored adult flukes. The collected snails were identified as Lymnaea truncatula and Lymnaea cailliaudi. Furthermore, larval stages of F. hepatica (sporocyts, rediae and cercariae) were reported in 41/731 (5.61\%) examined snails. However, L. cailliaudi snails were uninfetced. Using the conventional PCR, F. hepatica specific amplicon size of $1030 \mathrm{bp}$ was detected in isolates obtained from different localities. Detection of F. bepatica in the infected snails with mitochondrial DNA-targeting PCR was validated with the specific amplicon size. Based on the presence of snail intermediate host and the conventional PCR findings, Fasciola species in Dakhla Oasis were identified as F. hepatica. Accordingly, zoonotic importance and hygienic measures must be taken in consideration and highlighted by veterinarians and authorized agencies in both urban and rural areas.
\end{abstract}

Key words: Fasciola hepatica, cattle, infection, Galba truncatula, Dakhla Oasis, PCR

\section{INTRODUCTION}

Globally, fascioliosis is one of most important liver parasitic affections of herbivores caused by Fasciola spp. worms. The disease is a worldwide including a wide host range of grass-grazing animals such as sheep, goats, cattle, buffaloes, horses and rabbits (Soulsby, 1982). The Egyptian Academy of Scientific Research and Technology Report, highlighted on animal losses due to fascioliasis (about 190 million Egyptian pounds annually) (Eshazly et al., 2006). Moreover, Soliman (2008) mentioned that among patients admitted to hospitals suffering from fever of unknown origin, $4 \%$ had $F$. hepatica infection. $F$. hepatica has a wider range than its tropical counterpart, F. gigantica, but their geographical distribution overlaps in many African and Asian countries and sometimes in the same country, although in such cases the ecological requirement of flukes and their snail host are distinct (1980, Mas-Coma et al., 2005).In Egypt, the predominant species of Fasciola are Fasciola gigantica and Fasciola hepatica (Abdel-Nasser and Reffat, 2010; Dar et al., 2012).

Species of family Lymnaeidae are known for their role as intermediate hosts in the life cycle of Fasciola spp.
(Souslby, 1982). The most predominant and widespread (Europe, Asia, Africa and North America) intermediate host of $F$. hepatica is L. truncatula (Soulsby, 1982). Furthermore, Dar et al. (2005) found Lymnaea truncatula naturally infected with $F$. gigantica in Egypt and several snail species might contribute to the spread of fasciolosis in Egypt. In Ismailia Governorate, Egypt, L. truncatula and L. cailliaudi snails were recorded for the first time from East of Suez Canal (Hassan, 1999). An experimental infection of the snail with F. hepatica was done (Dar et al., 2014), suggesting that it is an important intermediate host for the induction of fasciolosis in Egypt. Egyptian isolate of $F$. hepatica miracidia could be easily developed in French $L$. truncatula snail showing a very low mortality and producing metacercariae higher in number than those noted in sympatric infections (Dar et al., 2012). Even though, there is paucity in information about reporting of F. hepatica in L. truncatula snails in Egypt.

The current study aimed to identify Fasciola spp. infection in cattle and to investigate its molluscan intermediate host with mitochondrial DNA-targeting PCR assay in Dakhla Oasis, El wadi Elgadid, Egypt. 


\section{MATERIALS AND MethodS}

\subsection{Cattle}

\subsubsection{Fecal samples}

Fecal samples of 300 cattle (107 males and 193 females) were collected from seven districts (El-Rashda, El- Hindo, El-Masra, El-Sheikhwali, Azab-Elqasr, El-Qasr and ElAweyna) in the Dakhla Oasis, El-Wadi Elgadid Governorate Egypt. Samples were directly collected from the rectum into plastic bottles with gloved hands, labeled by required data (age, sex, clinical signs, etc.) and brought to Dakhla Animal Health Research Laboratory (AHRL Dakhla). In the later, coproscopic examination was performed to detect the presence of Fasciolaspecies eggs by concentration sedimentation technique (Soulsby, 1982).

\subsubsection{Liver specimens}

In abattoir of Mout, Dakhla province, 285 cattle (135 males and 150 females) were subjected to post mortem inspection to investigate presence of different Fasciola species worms during the period from January to December 2014. Flukes were collected in saline and were transferred in an ice tank to the laboratory for further examination. Collected flukes were again washed in saline, fixed and stained according to Drury and Wallingten (1980) and were identified morphologically according to Soulsby (1982). For PCR assay, some intact adult flukes were preserved at $70 \%$ ethanol and stored at $-20 \stackrel{\circ}{C}$ till the DNA extraction.

\subsection{Lymnaeidae snails}

\section{Water source and snails collection}

Lymnaeidae snails (Fig. 1) were collected in clean bottles from the same districts in Dakhla province. The bottle cover was perforated to allow aeration for snails, and then

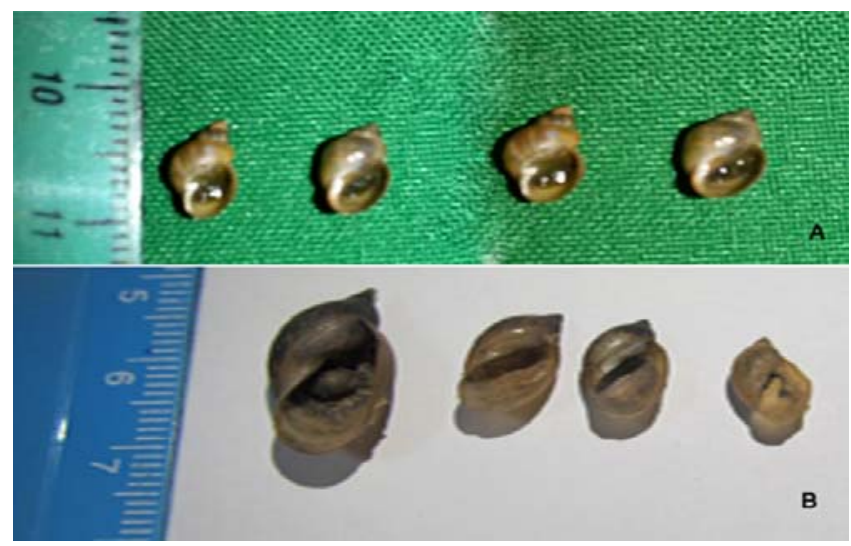

Figure 1: Lymnaeidae snails found in Dakhla Oasis, El-Wadi Elgadid governorate, Egypt

A. Lymnaea truncatula

B. Lymnae cailliaudi snails were transported to the laboratory for investigation. Collected snails underwent microscopy for the presence of different stages of Fasciola spp. infection by exposure technique (three to five snails were placed in a Petri dishes half filled with dechlorinated tap water and daily exposed to a direct light using 100 watt electrical lamb for a period of 2 hours (Abd El-Ghany, 1955). An alternative technique was used by crushing fresh snails directly in suitable Petri dishes with a few amount of water under dissecting microscope, where available parthenatae were recorded (Jackson, 1958). Snails were identified according the key provided by Prof. Santiago Mas-Coma, WHO, Madrid, Spain.

\subsection{Molecular identification of Fasciola species 2.3.1. Genomic DNA extraction}

DNA was extracted from infected snails and adult flukes collected from the different localities in Dakhla province. Microscopically infected snails were properly crushed. Moreover, five adult flukes from each region were thorough washed and their cone shape projections were cut with a sterile scalpel. Prior to DNA extraction, cone shape projections were crushed and homogenized and DNA was extracted by PureLink ${ }^{\circledR}$ Genomic DNA Kits (Invitrogen, USA) according to manufacturer instructions.

\subsubsection{DNA amplification}

Fasciola spp. mitochondrial DNA-targeting PCR assay was carried out to amplify the extracted genomic DNA from both infected snails and adult worms (Le et al., 2012b). The PCR mixture for Fasciola hepatica consisted of $1 \mu \mathrm{l}$ of the 10 pmol of FHF (GTTTTTTAGTTGTTTGGGGTTTG), and 1 $\mu \mathrm{l}$ FHGR (ATAAGAACCGACCTGGCTCAC), $3 \mu \mathrm{l}$ of DNA template, $12.5 \mu \mathrm{l}$ master mix (Biomatic ${ }^{\circledR}$ ). The reaction was completed to $25 \mu \mathrm{l}$ by adding $7.5 \mu \mathrm{l}$ nuclease free $\mathrm{H}_{2} \mathrm{O}$. The PCR mixture for Fasciola gigantica consisted of $1 \mu$ of 10 pmol FGF (TGTTATGATTCATTGTTTGTAG) and $1 \mu \mathrm{l}$ FHGR (ATAAGAACCGACCTGGCTCAC), $3 \mu$ of DNA template, 12.5 $\mu$ l master mix (Biomatic ${ }^{\circledR}$ ).

The reaction was completed to $25 \mu \mathrm{l}$ by adding $7.5 \mu \mathrm{l}$ nuclease free $\mathrm{H}_{2} \mathrm{O}$. Amplification was carried out by initial denaturation at $95^{\circ} \mathrm{C}$ for $3 \mathrm{~min}$, then 35 cycles, including denaturation at $95^{\circ} \mathrm{C}$ for $30 \mathrm{~s}$, annealing at $52^{\circ} \mathrm{C}$ for $30 \mathrm{~s}$, and extension at $72^{\circ} \mathrm{C}$ for $2 \mathrm{~min}$, and then a final extension for $7 \mathrm{~min}$ at $72^{\circ} \mathrm{C}$ to complete the amplification. The amplicon yielded by the FHF/FHGR primer pair is 1,031 bp, and that yielded by FGF/FHGR is 615 bp after visualization on $2 \%$ agarose. 


\section{RESULTS}

\subsection{Fecal examination}

Examination of 300 fecal samples revealed that 94 harbored Fasciola spp. eggs. Among those, 39.4\% (64/163) of examined females were infected (Table 1). It has been found that El-Rashda district was the highest infected among the 7 examined districts (Table 2).

\subsection{Findings of post mortem inspection}

It has been found that $33(11.56 \%)$ out of 285 examined animals had adult flukes in their bile ducts. Males less than 5 years had infection rate of $4.17 \%$. Meanwhile, cows exceeded 5 years showed the highest infection rate (18.0\%) (Table 1). Adult flukes were morphologically identified as Fasciola hepatica in all examined animals.

\subsection{Infection in snails}

Species of snails collected were identified as Lymnaea truncatula and L. cailliaudi. Snails were identified by WHO labs in Madrid through Prof. Mas-Coma. L. cailliaudi had no infection. L. truncatula was found to be infected by Fasciola spp. parthenatae. El-Rashda district showed the highest infection in L. truncatula snail (Table 2 and Fig. 2).

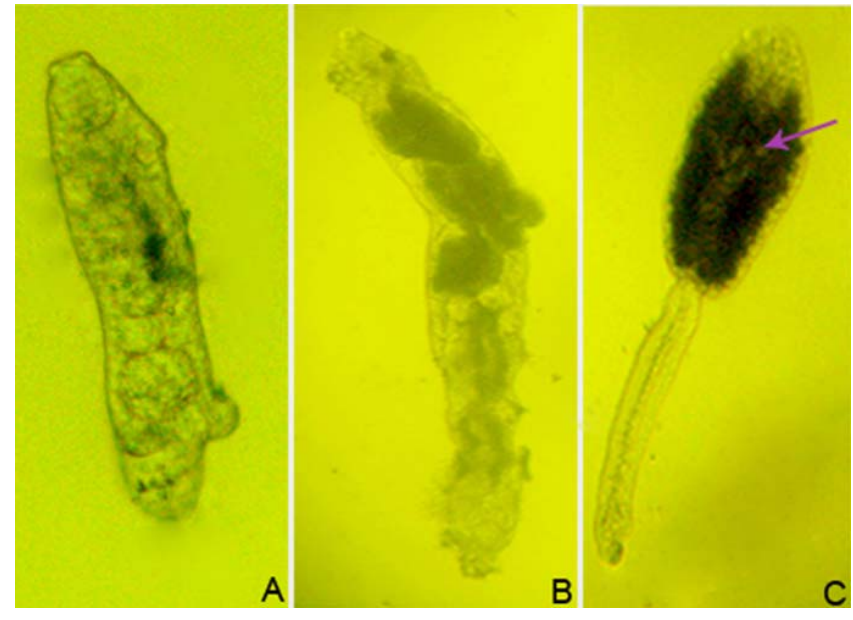

Figure 2: Larval stages of Fasciola hepatica obtained from $L$. truncatula snails

A. Immature redia

B. Redia

C. Cercaria

\subsection{Findings of conventional PCR}

Fasciola spp.-infected $L$. truncatula snails showed specific bands for F. Hepatica at 1,031 bp. Pooled samples obtained from the 7 districts revealed $F$. Hepatica showing specific bands of $1,031 \mathrm{bp}$. Control positive for $F$. gigantica was used to differentiate between $F$. hepatica and $F$. gigantica.

Table 1: Prevalence of Fasciola spp. infection in slaughtered animals and fecal samples in Dakhla Oasis relative to age and sex

\begin{tabular}{cccccc}
\hline \multirow{2}{*}{ Age } & \multirow{2}{*}{ Sex } & \multicolumn{2}{c}{ Liver inspection } & \multicolumn{2}{c}{ Fecal samples } \\
\cline { 3 - 6 } & & Examined No. & Infected No. (\%) & Examined No. & Infected No. (\%) \\
\hline \multirow{3}{*}{$<5$ years } & Male & 120 & $5(4.17)$ & 107 & $20(18.70)$ \\
& Female & 15 & $1(6.67)$ & 30 & $10(33.33)$ \\
$>5$ years & Male & 0 & 0.0 & 0 & 0.0 \\
& Female & 150 & $27(18.00)$ & $303(39.40)$ & $94(31.33)$ \\
\hline
\end{tabular}

Table 2: Distribution pattern of Fasciola spp. infection in slaughtered animals in seven districts of Dakhla Oasis

\begin{tabular}{|c|c|c|c|c|c|c|c|c|}
\hline \multirow{2}{*}{$\begin{array}{c}\text { Area } \\
\text { (Dakhla center) }\end{array}$} & \multicolumn{2}{|c|}{ Liver inspection } & \multicolumn{2}{|c|}{ Fecal samples } & \multicolumn{2}{|c|}{ Lymnaea truncatula } & \multicolumn{2}{|c|}{ L. cailliaudi } \\
\hline & $\begin{array}{c}\text { Exam. } \\
\text { No. }\end{array}$ & $\begin{array}{c}\text { Inf. } \\
\text { No.(\%) }\end{array}$ & $\begin{array}{l}\text { Exam. } \\
\text { No. }\end{array}$ & $\begin{array}{c}\text { Inf. } \\
\text { No. (\%) }\end{array}$ & $\begin{array}{c}\text { Exam. } \\
\text { No. }\end{array}$ & $\begin{array}{c}\text { Inf. } \\
\text { No. (\%) }\end{array}$ & $\begin{array}{c}\text { Exam. } \\
\text { No. }\end{array}$ & $\begin{array}{c}\text { Inf. } \\
\text { No. (\%) }\end{array}$ \\
\hline El-Rashda & 75 & $12(16.00)$ & 85 & $33(38.82)$ & 110 & $7(6.40)$ & 90 & $0(0)$ \\
\hline El-Hindo & 74 & $11(14.90)$ & 75 & $28(37.33)$ & 100 & $6(6)$ & 70 & $0(0)$ \\
\hline El-Masra & 35 & $4(11.43)$ & 40 & $12(30.00)$ & 150 & $10(6.66)$ & 100 & $0(0)$ \\
\hline El-Shiekhwali & 33 & $2(6.10)$ & 32 & $9(28.13)$ & 120 & $8(6.66)$ & 80 & $0(0)$ \\
\hline Azab-Elqasr & 29 & $2(6.90)$ & 28 & $7(25.00)$ & 80 & $5(6.25)$ & 50 & $0(0)$ \\
\hline El-Qasr & 20 & $1(5.00)$ & 20 & $3(15.00)$ & 95 & $3(3.20)$ & 40 & $0(0)$ \\
\hline El-Aweyna & 19 & $1(5.30)$ & 20 & $2(10)$ & 76 & $2(2.32)$ & 35 & $0(0)$ \\
\hline Total & 285 & $33(11.60)$ & 300 & $94(31.33)$ & 731 & $41(5.61)$ & 465 & 0 \\
\hline
\end{tabular}




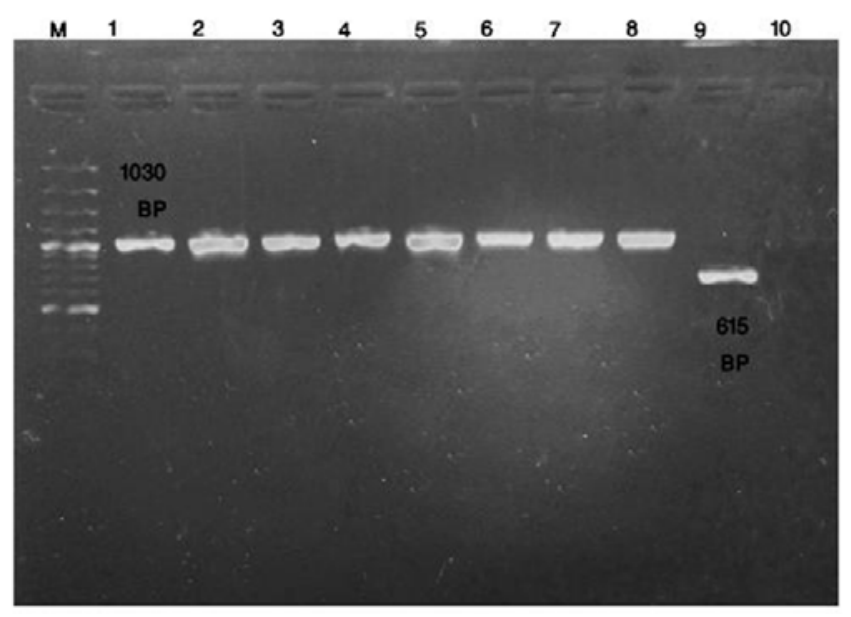

Figure 3: PCR amplification results for recovered flukes and infected $L$. truncatula snails

$\mathrm{M}$ is ladder of $500 \mathrm{bp}$

1: Fasciola infected L. truncatula snails

2-8: are samples of the different districts

9: F. gigantica control positive

10: Control negative

\section{Discussion}

Ascending clinically Fasciola spp.-infected cases in both domestic animals and humans throw a heavy light on public health and veterinary services, particularly in the under developed countries. Because of their significance referred to substantial economic losses in the livestock industry, effective methods for rapid and accurate detection of each parasitic stage as well as identification of Fasciola spp. species are highly needed for epidemiological surveys, clinical management, and infection control (Mas-Coma et al., 2009).

The prevalence of Fasciola spp. in livers of infected cattle in slaughterhouses, and in collected snails in Dakhla Oasis, Elwadi El-Gadid, Egypt carried out in the present study. In Mout abattoir, F. hepatica infection rate was $11.56 \%$. It was higher in cows than in bulls, and it was higher in senile animals ( $>5$ years) than younger. Similar results (11.97\%) were recorded by Jolanta and Agnieszka (2013) in Poland, Biuet al. (2013) (14.8\%) in Maiduguri, Nigeria. In the current investigation, the infection rate was lower than that obtained by Atallah (2008) in Egypt (18.5\%), On the other hand, it was higher than that detected by Ghoneim et al. (2011) who found an infection rate of $6.67 \%$ in Kalyobia, Egypt and Kadir et al. (2012) who revealed infection rate of $1.27 \%$.

Examination of 300 fecal samples showed $31.33 \%$ infected with Fasciola spp. eggs. Females $>5$ years had higher (39.4\%) infection rate than males (18.7\%). Similar results were revealed by Adedokun et al. (2008) in Nigeria, Avcioglu et al. (2014) in Erzurum Province, Turkey. On the other hand, lower infection rates were detected by Fufa et al. (2010) (4.9\%). Variations in infection rates could be related to geographical distribution, grazing system and different strategic control of helminthes.

Lymnaea truncatula is the most common intermediate host for F. hepatica worldwide (Bargues et al. 2012). Collected snails were identified as $L$. truncatula and $L$. cailliaudi. It has been found that $5.61 \%$ of $L$. truncatula snails were infected with Fasciola spp. Meanwhile, $L$. cailliaudi snails had no infection. In Egypt, L. truncatula was previously recorded uninfected from the Nile Valley and Delta (El-Shazly et al. 2012); Baharia, Dakhla, and Kharga Oases (Frandsen, 1983); the New Valley (AbdelGhani 1965, 1976); and Sinai (El-Kady et al., 2000). However, Egyptian populations of Lymnaea spp. snails were found naturally infected with Fasciola spp. (El-Shazly et al., 2012). Successful experimental infections with $F$. hepatica and $F$. gigantica were obtained under laboratory conditions (Dar et al., 2013).

Based on morphological criteria of the present flukes, they were identified as F. hepatica. Morphologic, morphoanatomic, morphometric and chemotaxonomic data were used to identify Fasciola spp. in Egypt (Lotfy and Hillyer, 2003; Periago et al., 2008; Abdel-Nasser and Reffat, 2010).

The common species of Fasciola in Egypt are Fasciola gigantica and Fasciola hepatica (Lotfy and Hillyer 2003; Dar et al., 2005; WHO, 2007; Dar et al., 2012). Moreover, Periago et al. (2008) investigated fasciolosis in Nile Delta, Egypt, and revealed the presence of $F$. hepatica, $F$. gigantica and intermediate forms (Fasciola sp.). AbdelNasser and Reffat (2010) in Qena, Egypt, differentiated morphologically 3 Fasciola species; Fasciola gigantica, Fasciola hepatica and two phenotypically different worms of F. hepatica.

To be identified, Fasciola spp. obtained from examined snails and from livers in abattoirs underwent mitochondrial DNA-targeting PCR assay. DNA was properly extracted from apical parts of pooled samples obtained from collected flukes and from infected $L$. truncatula snails. PCR amplification of the amplified samples revealed the presence of $F$. hepatica with specific amplicon size of $1031 \mathrm{bp}$. It is worthy to mention that, 
mitochondrial DNA targeting PCR succeeded to detect $F$. hepatica in the infected $L$. truncatula snails. Morphological, immunological, molecular, and combined approaches have been developed, including conventional PCR and multiplex PCR to identify Fasciola species. Previously developed PCR/real-time/multiplex PCR methods (Magalhães et al., 2004) used nuclear rather than mitochondrial targets for genetic characterization. Mitochondrial DNA is probably a better choice for a multiplex PCR application, due to its stability and the likely higher copy number even for a single egg (Le et al., 2012a). A mitochondrial duplex PCR have successfully developed and proved for identification of Fasciola spp. (Le et al., 2012a,b).

In conclusion, Fasciola hepatica and its intermediate host $G$. truncatula snails were recorded in seven districts of Dakhla Oasis, El-Wadi El-Gadid Governorate Egypt. Irrigation system and water sources, wells, were probably to be endemic with $L$. truncatula snails. Mitochondrial DNA-targeting PCR succeeded to detect and identify $F$. hepatica during liver inspection in abattoirs and its parasitic larval stages inside the infected intermediate host, L. truncatula snail. Special attention and safety precautions towards water used for both human and animal purposes must be considered to reduce the worm burden, minimize the infection and to overcome the zoonotic risk.

\section{Acknowledgement}

The authors appreciated great thanks for Prof. Mas-Coma for helping and confirmation of snails' identification.

\section{REFERENCES}

Abdel Ghany, A.F. (1955): Studies on the life cycle of trematodes of Egyptian domesticated animals, Ph.D. Thesis, Fac. Vet. Med, Cairo University.

Abdel Ghany, A.F. (1965): Lymnaea truncatula in the Nile Valley in Egypt. Proceeding of the $6^{\text {th }}$ Annual Veterinary Congress, Cairo, Egypt: 93-100.

Abdel Ghany, A.F. (1976): The present situation of Lymnaea snails in the New Valley. Proceeding of the $13^{\text {th }}$ Arab Veterinary Congress, Cairo, Egypt: 556-567.

Abdel-Nasser, A.H. and Refaat M.A.K (2010): Phenotypic description and prevalence of Fasciola species in Qena Governorate, Egypt with special reference to a new strain of Fasciola hepatica. J. King Saud Univ. Sci., 22, (1): 1-8.

Adedokun, O.A., Ayinmode, B.A and Fagbemi, B. 0 (2008): A comparative study of three methods for detecting Fasciola infections in Nigerian cattle. Veterinarski Arhiv 78 (5), 411-416.
Atallah, S.T. (2008): Economic losses from fascioliasis in slaughtered animals: at abattoirs levels. Minufiya Vet .j. Vol. 5 No. 2.

Avcioglu, H., Guven, E., Balkaya, I., Kaynar, O. and Hayirli, A. (2014): Evaluation of Coprological and Serological Techniques For Diagnosis of Bovine Fasciolosis. Israel Journal of Veterinary Medicine Vol. 69 (4).

Bargues, M. D., Artigas, P., Khoubbane, M., Ortiz, P., Naquira, C and Mas-coMa, S. (2012): Molecular characterisation of Lymnaea truncatula, Lymnaea neotropica and L. schirazensis from Cajamarca, Peru and their potential role in transmission of human and animal fascioliasis. Parasite. Vector. 5: 174.

Biu, A.A., Paul, B.T, konto, M. and Ya'uba, A.M. (2013): Cross Sectional and Phenotypic Studies on Fasciolosis in Slaughter Cattle in Maiduguri, Nigeria. Journal of Agriculture and Veterinary Sciences Volume 5, Number 2, ISSN: 2277-0062.

Dar, Y.D., Rondelaud, D and Dreyfuss, G. (2005): Update of fasciolosis-transmitting snails in Egypt (review and comment). J Egypt Soc Parasitol. 35(2):477-90.

Dar, Y., Amer, S., Mercier, A., Courtioux, BandDreyfuss, G. (2012). Molecular identification of Fasciola spp. (Digenea: Fasciolidae) in Egypt. Parasite. 19(2):177-82.

Dar, Y., Lounnas, M., DjuikwoTeukeng, F.F., Mouzet, R., Courtioux, B., Hurtrez-Boussès, S., et al. (2013): Variations in local adaptation of allopatric Fasciola hepatica to French Lymnaea truncatula in relation to parasite origin. Parasitol Res. 112(7):2543-9.

Dar, Y., Vignoles P., RondelaudandDreyfuss D., G. (2014): Role of the lymnaeid snail Pseudosuccinea columella in the transmission of the liver fluke Fasciola hepatica in Egypt. J Helminthol. 27:1-8.

Drury, R.A.B and Wallingten, E.A. (1980): Carleton's Histological Technique. (5th ed.) Oxford University Press.

El-Kady, G.A., Shoukry A., Reda I. A and El-badri, Y. S. (2000): Survey and population dynamics of freshwater snails in newly settled areas of the Sinai Peninsula. Egypt. J. Biol. 2: 42-48.

El-Shazly, A.M., El-Nahas, H.A., Soliman, M., Sultan, D.M., Abedl Tawab, A.H and Morsy, T.A. (2006): The reflection of control programs of parasitic diseases upon gastrointestinal helminthiasis in Dakahlia Governorate, Egypt J Egypt Soc Parasitol 36(2) 467-480.

El-Shazly, A.M., Nabih, N., Salem, D. A and Mohamed, M.Z. (2012): Snail populations in Dakahlia Governorate, Egypt, with special reference to lymnaeids. Egypt. J. Biol. 14: 45-49.

Frandsen, F. (1983): A field guide to freshwater snails in countries of the WHO Eastern Mediterranean region. Danish Bilharziasis Laboratory, Copenhagen, Denmark.

Fufa, A., Loma, A., Bekele, M and Alemayehu R (2010): Bovine fasciolosis: coprological, abattoir survey and its economic impact due to liver condemnation at Soddo municipal abattoir, Southern Ethiopia. Trop Anim Health Prod 42:289-292. 
Ghoneim, N.H., Hassan, M.A., El Newishy, A.M and Mahmoud, S.M. (2011): Fasciola as a zoonotic parasite in slaughtered animals at kalyobia abattoirs. Benha. Veterinary medical journal, vol. 22, no. 2: 207-213.

Hassan, M.G. (1999): Fascioliasis as a zoonotic parasite among animals, human and snails in Ismailia governorate. J Egypt Vet Med Ass 59(4) 1249-1269.

Jackson, J.H., (1958): Bilharezia, a back ground of its epedemicity and control in Africa with particular reference to irrigation scheme. South Afr J Lab Clin Med 4:1-54.

Jolanta, K and Agnieszka, L. (2013): The prevalence of Fasciola hepatica L. infection in cattle in the Lublin province in the years 2009-2012. Annals of Parasitology 59(4) 207-208.

Kadir, M.A., Ali, N.H. and Ridha, R.G.M. (2012): Prevalence of helminthes, pneumonia and hepatitis in Kirkuk slaughter house, Kirkuk, Iraq. Iraqi Journal of Veterinary Sciences, Vol. 26, Supplement III, (83-88).

Le, T.H., Nguyen, N.T., Truong, N.H. and De, N.V. (2012a): Development of mitochondrial loop-mediated isothermal amplification (mito-LAMP) for detection of the small liver fluke Opisthorchis viverrini (Opisthorchiidae; Trematoda; Platyhelminthes). J. Clin. Microbiol. 50:1178-1184.

Le, T.H., Nguyen, K. T., Nguyen, N.T.B., Doan, H.T., Le, X.T.K., Hoang, C.T.M., and De, N.V. (2012b): Development and Evaluation of a Single-Step Duplex PCR for Simultaneous Detection of Fasciola hepatica and Fasciola gigantica (Family Fasciolidae, Class Trematoda, Phylum Platyhelminthes). Journal of Clinical Microbiology 50,8, p. $2720-2726$

Lotfy, W.M. and Hillyer, G.V. (2003): Fasciola species in Egypt. Exp. Pathol Parasitol 6(11) 9-22

Magalhães, K.G., Passos, L.K.J and dos Santos, Carvalho. O. (2004): Detection of Lymnaea columella infection by Fasciola hepatica through multiplex-PCR. Mem. Inst. Oswaldo Cruz 99(4):421- 424.

Mas-Coma, S., Bargues, M.D and Valero, M.A. (2005): Fascioliasis and other plantborne trematode zoonoses. Int J Parasitol 35: 1255-1278.
Mas-Coma S, Bargues MD (2008): Human liver flukes: a review. Res Rev Parasitol, 57:145-218.

Mas-Coma, S., Valero, M.A and Bargues, M.D. (2009): Chapter 2. Fasciola, lymnaeids and human fascioliasis, with a global overview on disease transmission, epidemiology, evolutionary genetics, molecular epidemiology and control. Adv. Parasitol. 69:41-146.

Ngele, KaluKayong and Edward, I.B.E. (2014): Prevalence of fasciolopsis in cattle slaughtered at EKE market abattoir, Afikpo, Ebonyi state, Nigeria. Animal Research International 11(2): $1958-1963$.

Pantelouris, E.M. (1965): The common liver fluke Fasciola hepatica L. Pergamon Press, Oxford.

Periago, M.V., Valero, M.A., El Sayed, M., Ashrafi, K, El Wakeel, A., Mohamed, M.Y., Desquesnes, M., Curtale, F and Mas-Coma, S (2008): First phenotypic description of Fasciola hepatica/Fasciola gigantica intermediate forms from the human endemic area of the Nile Delta, Egypt. Infect Genet Evol 51-58.

Soliman, F.M. (2008): Epidemiological review of human and animal fascioliasis in Egypt. J Infect Developing Countries 2008; 2(3):182-189.

Souslby, E.J. (1982): Helminths, arthropods and domesticated animals. $7^{\text {th }}$ Ed., Bailliere, Tindall and Cassell, London. pp. 40-52.

Teklu, H., Abebe, $\mathbf{N}$ and Kumar. N (2015): Abattoir prevalence of bovine fasciolosis in the manucipal abattoir of Wukro, Northern Ethiopia. Journal of international academic research for multidisciplinary impact factor 1.625, issn: 2320-5083, volume 2, issue 12.

Umbreen, J.K and Maqbool, A. (2012): Prevalence of Fasciolosis in Cattle Under Different Managemental Conditions in Punjab. Pakistan J. Zool., vol. 44 (5), pp. 1193-1196.

WHO (2007): Report of the WHO Informal Meeting on use of triclabendazole in fascioliasis control. WHO/CDS/NTD/ PCT/2007.1 